\title{
Social Engineering to Establish Digital Culture in Higher Education
}

\author{
Tedi Priatna ${ }^{1, *}$, Dian Sa'adillah Maylawati ${ }^{2,3}$, Hamdan Sugilar ${ }^{4}$, Muhammad Ali Ramdhani ${ }^{2}$ \\ ${ }^{1}$ Department of Islamic Education, UIN Sunan Gunung Djati Bandung, Indonesia \\ ${ }^{2}$ Department of Informatics, UIN Sunan Gunung Djati Bandung, Indonesia
}

${ }^{3}$ Faculty of Information and Communication Technology, Universiti Teknikal Malaysia Melaka, Malaysia

${ }^{4}$ Department of Mathematics Education, UIN Sunan Gunung Djati Bandung, Indonesia

\begin{tabular}{l} 
A R T I C L E I N F O \\
\hline Article history: \\
Received: 18 September, 2020 \\
Accepted: 12 December, 2020 \\
Online: 21 December, 2020 \\
\hline Keywords: \\
Digital Culture \\
Digital Behavior \\
Higher Education \\
Information Technology \\
Organizational Culture \\
Social Engineering
\end{tabular}

\begin{abstract}
A B S T R A C T
This study aims to discuss the establishment of digital culture in higher education as an effort of higher education to align themselves with the development of science and technology so that that higher education is always at the forefront in the enforcement and provide high-quality education. The method used in this study is a qualitative method, which analyzes the causal relationship between the dimensions studied. Observation and literature review used as the main source of data/ information analyzed in this study. The analysis results showed that social engineering is an effective medium of modifying values, subjective norms, and rules for the creation of digital culture. The implication of this research shows that social engineering is an important activity that must be scheduled periodically by higher education as a medium for strengthening organizational culture to increase the capacity of human resources.
\end{abstract}

\section{Introduction}

World civilization moves together with the rapid development of information technology. The utilization of digital technology in all aspects of social life enters almost all lines of activities that regulate community life, including in the education field $[1,2]$. In Indonesia, higher education as an educational institution has the task of carrying out the Tridharma Perguruan Tinggi/ Higher Education Tridharma, namely education, research, and community service [3].

For carrying out functions optimally, higher education required to improve their business processes by adapting and adopting technology continually. The mastery of science and technology is substantive and elementary in the development of superior and modern universities. The diffusion of technology in business processes of higher education believed can create better performance in carrying out higher education Tridharma. Technology diffusion is an adaptation of higher education to its environment, by changing values, and making the work patterns of the academic community more systematic and efficient. One form of change from the diffusion of technology is the change of work culture into digital work patterns after this referred to as digital culture.

The digital culture was born from the phenomenon of digitalization in human civilization. Digital culture occurs because of the increasing uniqueness and importance of the technology application that encourages people to think about the importance of transforming significantly and dramatically [4]. Where finally, technology has an important role and becomes a necessity in the development of social culture [5,6]. Digitalization is a simplification of information material in the form of binary code or the integration of communication technology with computer logic. Data conversion methods have advantages in increasing the flexibility of handling, storing, processing, and sending data. The flexibility offered by the digitization process facilitates the process of transmitting and manipulating information materials that have an economic impact on a network, where information materials can be disseminated more efficiently among network users [7]. 
Several previous research that relevant to social engineering related to digital culture in higher education includes: (1) preparation of higher education in facing disruption of the digital era is a challenge in university branding, including adapting to the concept of virtual universities, virtual classes, artificial intelligent, and techno-entrepreneurship [8]; (2) guaranteeing the quality of education in the era of digital disruption in higher education is considered necessary, higher education which is one of the places to improve the quality of human resources needs to implement an internal guarantee system that is in line with the rapid development of digital technology [9]; (3) digital culture in higher education that the most frequently and widely used, especially for millennial students is e-learning/ digital learning/ virtual learning/ digital literacy [10-12], although on the other hand, learning in the classroom directly is still needed [13, 14]; (4) several models are created related to digital culture that will transform higher education into digital universities that are ready to compete in the era of technological disruption $[15,16]$, even online education policies and practices have supported the concept of digital university past, present and in the future [17]; (5) even in some studies discussing that digital culture in higher education can support the development of the digital economy [18], because the educational revolution towards technological progress is a revolution for the long term $[19,20]$. The novelty/ originality of this research lies in the focus of the study, which examines digital formation models for the development of the implementation of Tridharma in higher education.

\section{Research Method}

This research is policy research, where the product of this research expected to use as a foundation and consideration in the decision making of top university leaders. The methodology used in this study is qualitative research $[21,22]$ by collecting the literature review, observation, and Focus Group Discussion (FGD) [23]. The primary data source of this study refers to the results of observations, and literature reviews that have relevance to the objective conditions on the research object. Researchers use causal logic as a rational argument that connects the concepts which establish the organizational culture. Researchers in this study act as participant observers. This research conducted at UIN Sunan Gunung Djati Bandung (after this referred to as a university). This research puts digital culture as part of organizational culture. The main foundation used in this research is the need to shift the work culture that is manual towards digital culture as a consequence of technological developments and the demands of educational service users for technology-based prime services.

\section{Result and Discussion}

At the university, which is the object of research, 58 application programs have been designed and built as a modernization/ digitalization of the general business processes that run by the university. The design of the application program is aiming to optimize business processes carried out by the university. Figure 1 provides a detailed relationship between the main business process, supporting activities, and actors that run in the university.

Based on the results of discussions and interviews found the fact is not all application programs are running optimally. This case is allegedly due to low desire and the user's ability to run application programs. The integration of digital culture in the university's organizational culture is one solution to this problem. Organizational culture, according to many studies, can improve organizational performance [24-27].

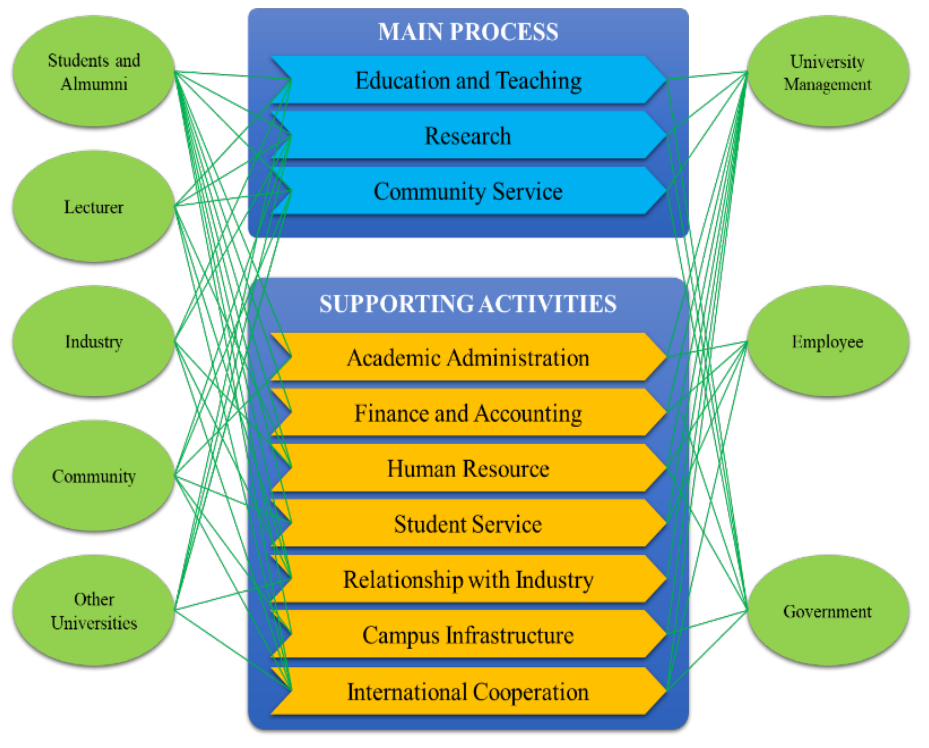

Figure 1: Process and Stakeholder Relations [28]

\subsection{Organizational Culture}

Organizational culture is a shared perception or a system of shared meanings shared by its members. The function of organizational culture is to determine the roles that distinguish organizations from others, define shared goals that are greater than individual interests, maintain social stability, enhance identity for members of the organization, and provide control mechanisms that provide guidelines for attitudes and behavior [29].

Organizational culture at the university will foster an individual's identity as a process of personal assimilation as part of the academic community. The similarity of embedded values will make it easier for every academic community to understand and appreciate every activity carried out by the university. An understanding of the organizational culture at the university will facilitate the resolution of internal problems such as giving awards, work ethics, and career development. This understanding will also help universities in overcoming external issues so that universities can do the best service.

Factors that lead to the development of organizational culture consists of internal and external factors, modifying/ changing the culture of the organization will create existing human resources will be of higher quality [30]. The organizational culture that is the color of the research object is the work culture of the Ministry of Religion (MORA) of Republic Indonesia. Structurally, the university which used as a research locus is a work unit that is under the authority of MORA. The work culture adopted at MORA includes integrity, professionalism, innovation, responsibility, and exemplary [31]. The alignment of work culture to a digital culture presented in Figure 2. 


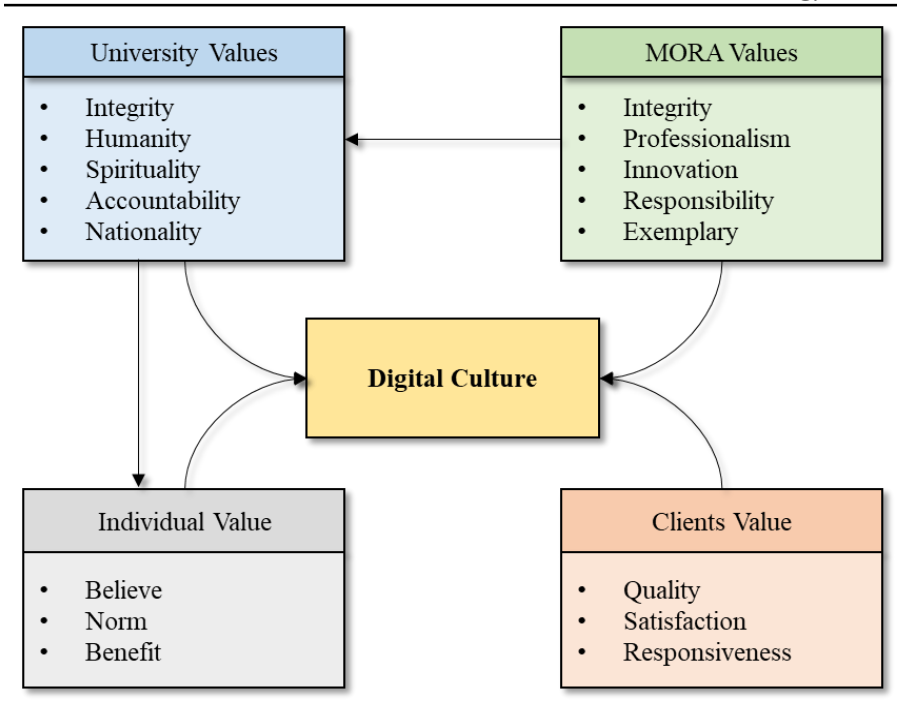

Figure 2: Alignment of Work Culture in Digital Culture

\subsection{Digital Culture}

Digital culture is a behavioral habit that utilizes digital technology as part of its work. The formation of digital culture is essential in sustaining the main tasks of the university. In general, individual activities motivated by the culture that influences their behavior. Culture requires individuals to behave and give instructions to them about what must be followed and learned. An influential culture can create a bond between the university and the academic community and inspire to create university excellence. The digital culture built by values, norms/ ethics, and regulations, which expressed in the form of behavior. Figure 3 describes the dimensions of forming behavior in digital culture.

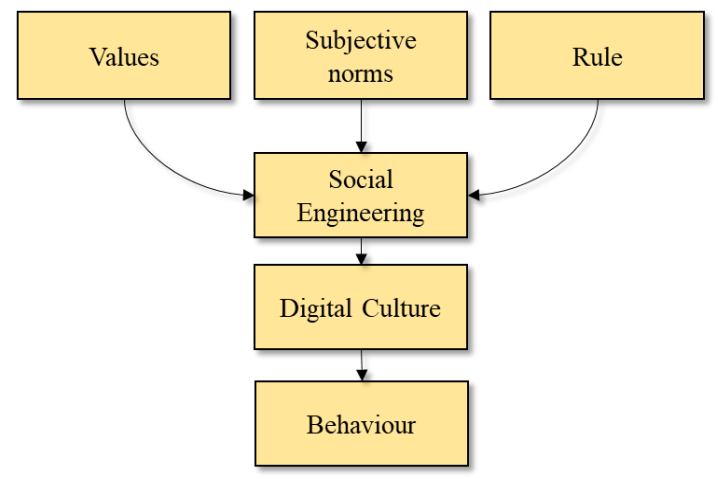

Figure 3: Dimensions of Forming Behavior in Digital Culture

\subsubsection{Value}

Values are all things related to human behavior regarding good or bad as measured by religion, tradition, ethics, morals, and culture that apply in society [32]. The definition of value used in this article is an individual's understanding of the elements of goodness that give meaning to his status.

Digital culture in the academic community requires value as an individual motivation to conduct digital-based behaviour. The value dedicated to the academic community includes strengthening personal beliefs about the value of goodness, which realized by working professionally and innovatively as part of worship. Digital culture will provide position and imaging for the academic community as individuals who are good at carrying out the activities in the social community.

\subsubsection{Subjective Norm}

Subjective norms are one's perceptions of the thoughts of those who considered to have a role and have hope for him to do something and the extent of the desire to fulfill these expectations. The concept of subjective norms is a representation of the demands or pressures of the environment lived by the individual and showed the individual's belief in the existence of approval or not from social figure [33], [34]. Norms generally formed on the convergence of the values of goodness to individuals in the group. The norm that developed in digital culture is the desire always to improve things. Norms implemented lead to forms of appreciation or social sanctions for the implementation of digital culture.

\subsubsection{Regulation}

Regulations are written decisions regarding binding behavior, which contain provisions regarding rights, obligations, functions, status, or order. Rules established and issued by the authorized institution [35]. Because it is binding, this regulation can shape digital culture as part of personal obligations in carrying out its activities on campus. The effectiveness of university regulations can do by applying formal awards and sanctions for the implementation or violation of its commitments as an academic community.

\subsubsection{Behaviour}

Behaviour in general terminology can translate as all actions or actions carried out by humans, which can be observed directly or indirectly [36]. Behaviour is a function of the relationship between the individual and his environment. Different environments can determine differences in human behaviour between one another [37]. Based on a biological perspective, the behaviour is an activity or activity of the organism in question. Behavioural symptoms that can observed directly from organisms influenced by environmental and genetic factors (heredity). The mechanism of fusion and the meeting between the two elements is called the learning process [38].

Behaviour is a mental condition (thinking, opinion, attitude, and etcetera) that reacts to the status that exists outside the object. The reaction can be in the form of an active response accompanied by action. Simply stated, behaviour can refer to as an action taken by a person or group of people based on particular interests or needs based on the values, knowledge, and norms of the group concerned.

Educational psychologist Benjamin Bloom divides human behavior into three elements [39], among others:

1) Cognitive. The cognitive item includes an individual's beliefs that are related to the way individuals perceive the object of attitude to the responses they see and know (knowledge) based on their views, thoughts, beliefs, emotional needs, personal experiences, and information from others. 
2) Affective. The affective element refers to the subjective psychological aspects of individuals towards the object of attitude, both positive and negative. Emotional reactions are primarily determined by what believed to be good or harmful to the object of the attitude.

3) Psychomotor. The psychomotor element is also called the behavioural component, which is the attitude component related to predisposition or the tendency to act on the object of the attitude it faces.

In general, human behaviour is an instrument of response (operant response) as a response that is born and develops on specific stimuli. Therefore, certain conditions (operant conditioning) need to be created to form the type of response/ behaviour [39]. The stages of developing behaviour in operant conditioning carried out as part of digital culture are:

1) The introduction of reinforcement elements in the form of rewards/ prizes for the behaviour to be established;

2) Analysis of the components forming the desired behaviour, which arranged in sequence for the formation of the desired behaviour;

3) For the implementation phase the sequence of the components is accompanied by the determination of tentative (temporary) objectives and identification of reinforcements for each component;

4) Carry out a sequence of components that have arranged as a behaviour formation activity.

In the implementation of digital culture, it is necessary to emphasize the importance of collaboration between individuals, so the planned goals will run according to what desired.

\subsection{Social Engineering}

Humans created as individual creatures and social beings; socializing is a characteristic of humans and is a natural tendency in living the activities of human life. In the context of individual beings, human beings given physical characteristics and characters that make the difference between humans and other individuals; if they are part of a unified social group, they will experience the process of socialization [40]. In the process of socialization with groups/ communities, individuals often have different perspectives that can trigger conflicts of interest, which referred to as social problems. The social problem is the gap between how an individual behaves who seen as opposed to the norm agreed upon by the community members [41]. Social issues are closely related to norms, moral values, and social institutions [42].

The results of research observations can see the gap in the use of information systems applications that have been provided by the university. It is found groups who optimally use information systems, on the other hand, found the academic community who rarely use the information system as a work support tool. In addition to the problem of professionalism, in the context of organizational culture, researchers see this gap as a social problem. To overcome social issues, it is necessary to do the social transformation that emphasizes individual adaptation to social norms and institutions (digitizing policies) that apply. The next stage is changing one's behaviour as aligning itself with these values.

A more systematic and planned social transformation generally carried out through a process of social engineering. In social engineering, the object is the community to form a better system and system as desired by the engineer (the social engineer). Social engineering begins with the emergence of social problems, namely the imbalance between das-sein and das-sollen, or what happens is not following the expectations of the organization (university). Social engineering is a social planning that leads to the realization of social transformation, which is supported by the internalization of humanization values [40].

Social engineering is a process of social change that is systematic and planned to deal with social problems that implemented using various strategies and stages to make social change happen as desired. For social engineering to run effectively and efficiently, the planning, implementation, and evaluation activities of social engineering activities must involve all stakeholders [43]. Social engineering is not only used for inculcation and strengthening patterns of habits and behavior, but also used to direct the desired goals, eliminate habits that deemed unnecessary/ unsuitable, create new patterns of behavior, and etcetera [44]. Culture can form through formal assignments and habituation processes [45].

Education/ training, from a particular perspective, can be understood as social engineering, where education/ training will provide a fundamental influence in the process of social change. In education, there is a planting of universal values that will change the human paradigm so that humans can have the ability to think critically objectively $[40,46]$. Education/ training in this context can be understood as a process of increasing understanding of professionalism and innovation that realized in digital culture.

The education/ training process can be useful if a learning module is available [47], open space for discussion/ debate [48], good implementation process, and involve all parties. The process of education/ training to create a work culture is to form workers' attitudes towards work (work attitudes). This attitude is determined and influenced by three factors, namely: involvement in work, job satisfaction, and work commitment. These three factors are interrelated with one another [49].

In higher education, to establish the digital culture of academic community (especially lecturer, educational personnel, and student as main stakeholders), social engineering is become one of important strategy. Research found that social responsibility attitude and behavior can influence the user satisfaction in higher education, especially for student [50]. More than just being "literate" in technology, social engineering including habits, attitudes and behavior of the academic community in higher education is a trigger to improve the digital culture. Starting from the policies and support of top management, to fostering habits in the use of technology and the creation of a digital culture atmosphere. 


\section{Lack of the Study}

This study specific to the perspective of digitalization in Higher Education. While, one perspective could be the digitization of education by itself. Within this topic not only social engineering is important but also technical engineering of the used technology. Another perspective could be worldwide digital technology transformation which then becomes a central perspective for studying by the teachers and students. With this central perspective teachers and lecturers could be acquainted with the development of new digital technologies which are of will be used in the coming years.

\section{Conclusion}

A digital culture is a form of higher education adaptation in facing various dynamics of technological development. Digital culture is a modification of the organizational culture that has existed at higher education, with reinforcement in technology/ digital-based work behavior. This research creates a formulation model to enhance the digital culture for the development of main activities in higher education. This model of digital culture implements the university value, MORA value, individual value, and client (technology user) value. The process of cultural formation can carry out with social engineering by modifying values, subjective norms, and work rules. Then, social engineering can change the digital culture to be behavior. For the implementation of digital culture, social institutions take precedence over the formal administrative approach. Therefore, for the further works, the social engineering can be implemented and the behavior of digital culture in higher education can be evaluated and enhanced.

\section{Conflict of Interest}

The authors declare no conflict of interest.

\section{Acknowledgment}

The authors would like to appreciate and thank UIN Sunan Gunung Djati Bandung academic community for supporting this research.

\section{References}

[1] H. Harun, "Kesiapan Pendidikan Tinggi dalam Menghadapi Revolusi Industri 4.0 dalam Perspektif Kelembagaan," in Prosiding Seminar Nasional, Universitas Cokroaminito Palopo, Palopo: 187-194, 2018.

[2] V.G. Gerasimova, M.R. Melamud, D.R. Tutaeva, Y.D. Romanova, N.A. Zhenova, "The adoption of e-learning technology at the faculty of distance learning of plekhanov russian university of economics," Journal of Social Studies Education Research, 9(2), 172-188, 2018. https://jsser.org/index.php/jsser/article/view/254

[3] B. Lian, "Tanggung Jawab Tridharma Perguruan Tinggi Menjawab Kebutuhan Masyarakat," in Seminar Nasional Program Pascasarjana Universitas PGRI Palembang, 100-106, 2019.

[4] C. Gere, Digital culture, Reaktion Books, 2009.

[5] V. Miller, Understanding digital culture, SAGE Publications Limited, 2020.

[6] L. Muliawaty, K. Alamsyah, U. Salamah, D.S. Maylawati, "The concept of big data in bureaucratic service using sentiment analysis," International Journal of Sociotechnology and Knowledge Development, 2019, doi:10.4018/IJSKD.2019070101.

[7] M. Ezmieralda, "Budaya Digital dan Perubahan Konsumsi Media Masyarakat," in Seminar Nasional FISIP-UT 2010, Universitas Terbuka, Tangerang Selatan, 2010.

[8] M.N. Yunus, U., Heriyati, P., Lindawati, A., \& Willyarto, Branding
Perguruan Tinggi di Era Digital, Penerbit Qiara Media, 2019.

[9] B.S. Putra, A. Rohman, K. Diantoro, A. Soderi, W.R. Puteri, "IMPLEMENTASI SPMI SEBAGAI UPAYA PERGURUAN TINGGI MENGHADAPI ERA 5.0," Quality Assurance Practice, 1(1), 2019.

[10] L.R. Salazar, E. Diego-Medrano, "The Role of Millennial Students in Shaping the Digital Learning Culture in Higher Education," Examining Millennials Reshaping Organizational Cultures: From Theory to Practice, 123, 2018.

[11] P.S. Kiser, M. Abdoney, E.A. Teaff, "Black Mirrors and Digital Culture: Digital Citizenship through Pop Culture," 2019.

[12] J. Potter, J. McDougall, Digital media, culture and education: Theorising third space literacies, Springer, 2017.

[13] C. Costa, M. Murphy, A.L. Pereira, Y. Taylor, "Higher education students' experiences of digital learning and (dis) empowerment," Australasian Journal of Educational Technology, 34(3), 2018. https://doi.org/10.14742/ajet.3979

[14] S. Lange, C. Robertson, "How is digital culture influencing your practice?," Spark: UAL Creative Teaching and Learning Journal, 2(2), 139-143, 2017.

[15] J. Khalid, B.R. Ram, M. Soliman, A.J. Ali, M. Khaleel, M.S. Islam, "Promising digital university: a pivotal need for higher education transformation," International Journal of Management in Education, 12(3), 264-275, 2018. https://doi.org/10.1504/IJMIE.2018.092868

[16] M.A. Peters, P. Jandri, "Peer production and collective intelligence as the basis for the public digital university," Educational Philosophy and Theory, 50(13), 1271-1284, 2018.

[17] A.G. Picciano, Online education policy and practice: The past, present, and future of the digital university, Taylor \& Francis, 2016.

[18] E.A. Khitskov, S. V Veretekhina, A. V Medvedeva, O.L. Mnatsakanyan, E.G. Shmakova, A. Kotenev, "Digital transformation of society: problems entering in the digital economy," Eurasian Journal of Analytical Chemistry, 12(5b), 855-873, 2017.

[19] A. Kalache, "An education revolution in response to the longevity revolution," Revista Brasileira de Geriatria E Gerontologia, 22(4), 2019 https://doi.org/10.1590/1981-22562019022.190213

[20] J. Gagliardi, A. Parnell, J. Carpenter-Hubin, "The Analytics Revolution in Higher Education," Change: The Magazine of Higher Learning, 50(2), 22 29, 2018, doi:10.1080/00091383.2018.1483174.

[21] Sharan B. Merriam, Qualitative Research: A Guide to Design and Implementation, 2009, doi:10.1017/CBO9781107415324.004.

[22] J.A. Maxwell, L.E. Reybold, Qualitative Research, 2015, doi:10.1016/B9780-08-097086-8.10558-6.

[23] M. a Masadeh, "Focus Group : Reviews and Practices," International Journal of Applied Science and Technology, 2012.

[24] M.A. Mahfouz, D.A. Muhumed, "Linking organizational culture with financial performance," Bussecon Review of Social Sciences (2687-2285), 2(1), 38-43, 2020, doi:10.36096/brss.v2i1.171.

[25] M.R. Saif, N.K. Bin Yeop, "The Effect of Organizational Culture on Knowledge Management and Managerial Performance of Government Department in Dubai," European Journal of Multidisciplinary Studies, 5(1), 47-53, 2020, doi:10.1002/kpm.344.

[26] E. Cera, A. Kusaku, "Factors Influencing Organizational Performance: Work Environment, Training-Development, Management and Organizational Culture," European Journal of Economics and Business Studies, 6(1), 16-27, 2020. https://dx.doi.org/10.26417/ejes.v6i1.p16-27

[27] D. Lee, "Impact of organizational culture and capabilities on employee commitment to ethical behavior in the healthcare sector," Service Business, 14(1), 47-72, 2020, doi:10.1007/s11628-019-00410-8.

[28] W. Darmalaksana, M.A. Ramdhani, R. Cahyana, A.S. Amin, "Strategic Design of Information System Implementation at University," International Journal of Engineering \& Technology, 2018, doi:10.14419/ijet.v7i2.29.14257.

[29] E.A. Sudanang, S.E. Priyanto, "Pengaruh Kepuasan Kerja dan Budaya Organisasi terhadap Produktivitas Kerja Karyawan di Horison Apartemen dan Kondotel Yogyakarta," Kepariwisataan: Jurnal Ilmiah, 14(1), 31-36, 2020.

[30] M.H. Yusuf, "Pengembangan Budaya Organisasi dalam Lembaga Pendidikan," Tarbawi: Jurnal Pendidikan Islam, 14(1), 81-96, 2017. https://doi.org/10.34001/tarbawi.v14i1.613

[31] Z.S. Thontowi, M. Qowim, A. Dardiri, "Implementasi Lima Nilai Budaya Kerja di Kantor Kementerian Agama Kabupaten Banyumas," FIKROTUNA, 9(1), 1160-1178, 2019.

[32] Q.Y. Zaqiah, A. Rusdiana, Pendidikan Nilai: Kajian Teori dan Praktik di Sekolah, 2014

[33] D. Kurniawati, S. Sumarji, "Pengaruh Pengetahuan, Persepsi, Sikap, dan Norma Subyektif terhadap Perilaku Konsumen Muslim dalam Konsumsi 
Produk Pangan Halal di Kabupaten Nganjuk,” Manajemen Agribisnis: Jurnal Agribisnis, 18(1), 49-52, 2020.

[34] R.R. Agustin, N. Diana, A. Afifudin, "Pengaruh Ekspektasi Pendapatan, Motivasi, Pendidikan Kewirausahaan, dan Norma Subyektif terhadap Minat untuk Berwirausaha,” Jurnal Ilmiah Riset Akuntansi, 9(04), 2020.

[35] N. Qamar, F.S. Rezah, Ilmu dan Teknik Pembentukan Peraturan PerundangUndangan, Social Politic Genius (SIGn), Makasar, 2020.

[36] S. Notoatmodjo, Pendidikan dan Perilaku Kesehatan, Rineka Cipta, Jakarta, 2003.

[37] S.P. Robbins, T.A. Judge, Perilaku Organisasi, Gramedia, Jakarta, 2010.

[38] T.H. Basri, Hubungan Tingkat Pengetahuan tentang Makanan Berserat Dengan Pola Konsumsi Makanan Berserat pada Mahasiswa Angkatan 20082011 Fakultas Kedokteran Universitas Lampung, Universitas Lampung, 2012.

[39] S. Notoatmodjo, Promosi Kesehatan: Teori dan Aplikasinya, Rineka Cipta, Jakarta, 2007.

[40] T. Syarofi, Studi Analisis Pemikiran Jalaludin Rahmat tentang Social Engineering dan Relevansinya dengan Tujuan Pendidikan Islam, Institut Agama Islam Negeri Walisongo, 2010.

[41] M. Soelaiman, Teori Sosial Dasar: Teori dan Konsep Ilmu Sosial, Rafika Aditama, Bandung, 2001.

[42] P. Jones, L. Bradbury, S. Le Bouttilier, Pengantar Teori-teori Sosial: Dari Teori Fungsionalisme Hingga Postmodernisme, Yayasan Obor Indonesia, Jakarta, 2016.

[43] E. Susilowati, Windiani, "Pendekatan Rekayasa Sosial dalam Pengelolaan Sumberdaya Air: Studi Kasus Pengadaan Tanah untuk Pembangunan Bendungan Semantok di Kabupaten Nganjuk-Jawa Timur," in Seminar Nasional Strategi Pembangunan Nasional Menghadapi Revolusi Industri 4.0, $1-12,2018$.

[44] A.L. Diab, "Peranan Hukum sebagai Social Control, Social Engineering, dan Social Welfare," Jurnal Al-'Adl, 7(2), 53-66, 2014.

[45] M.S. Mazaya, H. Ainissyifa, "Character education through the obligation to wear santri's dress," in Proceedings of the International Conference on Islamic Education (ICIE 2018), Atlantis Press, Paris, France: 309-311, 2018, doi:10.2991/icie-18.2018.56.

[46] T. Borodina, A. Sibgatullina, A. Gizatullina, "Developing Creative Thinking in Future Teachers as a Topical Issue of Higher Education," Journal of Social Studies Education Research, 10(4), 226-245, 2019. https://doi.org/10.1590/1981-22562019022.190213

[47] M.S. Mazaya, "Effective practical learning model for the subject of basic information technology," Journal of Physics: Conference Series, 1157, 42003, 2019, doi:10.1088/1742-6596/1157/4/042003.

[48] M.S. Mazaya, "Logical framework for smart discussion in learning process," Journal of Physics: Conference Series, 1157, 42002, 2019, doi:10.1088/1742-6596/1157/4/042002.

[49] M.R.K. Umam, "Peran Islamic Management Principles pada Pembentukan Corporate Culture untuk Meningkatkan Kinerja Sumber Daya Manusia pada Organisasi Bisnis," Eka Cida, 1(1), 110-124, 2016.

[50] D. Gallardo-Vazquez, J.A. Folgado-Fernandez, F. Hipolito-Ojalvo, L.E. Valdez-Juarez, "Social Responsibility Attitudes and Behaviors' Influence on University Students' Satisfaction," Social Sciences, 9(2), 8, 2020. https://doi.org/10.3390/socsci9020008 